\title{
Legal Protection on Notary Who Made a Suspect in His Duty
}

\author{
Ine Rizka Ariyani ${ }^{1}$; Bruyi Rohman Warsito ${ }^{2}$ and Gunarto 3
}

Abstract. Provisions concerning Notary regulated in Act No. 2 of 2014 on the Amendment of Act No. 30 of 2004 concerning Notary (hereinafter referred UUJN). In Article 16 paragraph (1) letter (e) states that a Notary UUJN must preserve the confidentiality of all information obtained for a deed in accordance with their oath of office. In facing legal issues, Notary need an organization that can accommodate the aspirations and the problems it faces, so precisely that the Indonesian Notary Association (INI) into an organization that has continuity in carrying out the supervision, guidance and legal protection for a notary.

The research objective is to analyze the legal protection of a notary is used as a suspect in the running of their office, to analyze problems and solutions of legal protection against notaries who serve as a suspect in carrying out his duties.

The method used in this research is juridical empirical method is a method of legal research that attempts to view the law in terms of real or can be said to see, examine how the workings of the legal community.

The results of this study finally provides an answer that before a notary dragged to criminal law to the case of giving false testimony, the investigator must know what the principal case of the case. Due to lack of caution can make Notary as a suspect. Notaries in carrying out its duties merely formal and only constantire wishes of the parties and then poured into deed. Because there is one of the aggrieved party in the matter and notary asked by investigators to show the deed and is of public interest and obtain permission from MKN, then Article 16 (1) $\mathrm{f}$ and Article 54 UUJN about keeping positions can be ruled out because there are interests higher should notary testified that noataris released from his oath of office according to the rules applicable legislation. MKN legal protection given to the Notary ie if it will initiate an investigation or calling to the Notary must ask permission first terelebih to MKN, must coordinate with the IT organization or the competent senior Notary.

Keywords: Legal Protection; Suspect; Notary.

\section{Introduction}

Indonesia is a country of law, then the law has the highest position in the government and the law is the protection of human interest. ${ }^{4}$ The law regulates all legal relations between individuals, individuals with society and the individual with the government. ${ }^{5}$

Notary is an honorable profession and always concerned with morals and ethics when performing his respective duties. When performing his respective duties notary cling and uphold the dignity of the profession as positions of trust and honor, because adherence to the ethics of the notary profession is referred to as a noble profession (officium nobile). ${ }^{6}$ Community life growing impact on the increasing demand for public services that can

\footnotetext{
${ }^{1}$ Students Master of Notary Law, Faculty of Law, Universitas Islam Sultan Agung, e-mail : rizkaariyani95@gmail.com

2 Students of Master of Law, Faculty of Law, Universitas Islam Sultan Agung email rohmanbruyi@gmail.com

${ }^{3}$ Faculty of Law UNISSULA, Semarang

${ }^{4}$ Sudikno Mertokusumo, Mengenal Hukum Suatu Pengantar, Liberty, Yogyakarta, 2003. p 21.

${ }^{5}$ Mochtar Kusumaatmadja, Pengantar IImu Hukum Suatu Pengenalan Pertama Ruang Lingkup Berlakunya IImu Hukum, Alumni, Bandung, 2000, p.43.

${ }^{6}$ Abdul Ghofur Anshori, Lembaga Kenotariatan Indonesia, Perspektif Hukum dan Etika, UII Press, Yogyakarta, 2009, p. 6.
} 
provide legal certainty, one of them in the field of notary services. Public services provided by the notary deed in the form of services and other tasks assigned to the notary who is attached to the title as a public official in the scope of duties and authority of the notary. Deed made by the notary as a public official authorized by the State must be able to be strong evidence in case of disputes or cases in various areas of law including legal disputes in court, meaning the notarial deed gives an assurance to the parties will be proving perfect, Juridical protection is expected to have a basic standard. The government has a concern and confidence in the academic world are expected to exercise control carried Notary to the positions and behavior. Facilities and infrastructure required to do so as a means of education, upgrading or refreshing again Supervisory Council of academia and government can go hand in hand knowledge possessed of the work of the Notary. Matters of administrative tasks that nature can be studied and learned quickly. Assembly supervisor of origin as organizational elements notaries who know and understand the notary practices. This is because they come from the Notary who care with good personality, community and friends with the same profession recognizes and integrity and dedicated. ${ }^{7}$

A person may be a witness, suspect or defendant may arise, for various reasons, can be intentional or unintentional, but under any pretext, if found guilty, the Notary had violated his oath itself and coupled with make deed false because it does not run the office properly. ${ }^{8}$ In the case of a notary also called in a particular case, where it is used as a witness or a suspect or even as a defendant, the extent to which the protection he obtained as a public official who runs the office, if he is processed in a manner generally consistent with the Book Law of Civil Procedure and the Book of the Law of Criminal Procedure.

In Article 16 paragraph (1) letter (e) states that a Notary UUJN must preserve the confidentiality of all information obtained for a deed in accordance with their oath of office. This article is an arrangement of the right of refusal for the Notary, so it can be used for Notaries in running the oath of office

The rise of the call investigators to the notary as a public official deed authentic aimlessly with the perfect start to doubt the evidence by law enforcement (in this case the investigators) can be seen through easily notary called in for questioning. This happened since the release of the decision of the Constitutional Court Number 49 / PUU-X / 2012 which remove some of the sentence in Article 66 UUJN which essentially frees calling notary by investigators directly, without permission Regional Supervisory Council. After the promulgation of UUJNP which to reinsert Article 66 which essentially requires the investigator to ask for permission to call the Honorary Council of Notaries for Notaries, but until now the implementing regulations for the establishment of a Notary Honorary Council has not yet formed, so the calling Notary fixed directly without permission to refer to the decision of the Court. Actually, without calling Notary all matters relating to the case had been stated in the deed of Notary as perfect evidence. This is where the role of the Indonesian Notary Association organization is required to provide protection to the notary in the investigation process in order to remain dignified profession Notary has the eyes of society.

In facing legal issues, Notary need an organization that can accommodate the aspirations and the problems it faces, so precisely that the Indonesian Notary Association (INI) into an

\footnotetext{
${ }^{7}$ Irawan Arif Firmansyah, Sri Endah Wahyuningsih, Peran Notaris Sebagai Saksi Dalam Proses Peradilan Pidana, Jurnal Akta, Sultan Agung Islamic University in Semarang, Vol. 4 dated 3 September 2017.

${ }^{8}$ Tan Thong Kie, Studi Notariat, Jakarta : PT. Ichtiar Baru Van Hoeve, 2000, p.262
} 
organization that has continuity in carrying out the supervision, guidance and legal protection for a notary, in the world of notaries there is no doubt that so many of the problems faced by the Notary and takes the role of INI organizations to find solutions to these problems.

Based on the description above, the authors are interested in and will be stated in the form of legal writing titled "Legal Protection On Notary Who Made A Suspect In His Duty". This research aims to To analyze the legal protection of the Notary used as a suspect in carrying out his duties; and To analyze the constraints and the solution of legal protection against notaries who serve as a suspect in carrying out his duties.

\section{Research methods}

The approach used in this study is primarily empirical juridical approach. Empirical jurisdiction is a legal research methods that attempt to view the law in terms of real or can be said to see, examine how the working of the law in society. ${ }^{9}$ In this case the juridical approach is used to analyze various regulations concerning the Notary office, while the empirical approach used to analyze the legal views of the behavior of people in public life, always interacting and relating with the community aspects. ${ }^{10}$ Data collection techniques using literature study and interviews. Notary who in an interview by the author is Mr. Anisitus A Gaham. Examples of the problems given in accordance with the above thesis title is: the act of buying and selling land, husband and wife (sellers) and buyers came to the notary to be made a deed of sale. Notaries do not know that that was taken by her husband (the seller) is not the legitimate wife. But the seller said that he (she) is really the only one legal wife while his legal wife at the time was located outside the city. After 1 (one) year and then turns his legal wife to come home and find the deed to the land was already there. And there is a neighbor who says the land has been sold to people for Notary A. ${ }^{11}$ And his wife come to the notary office and report to the police that the notary also suspected following give the false witnesses (Article $264 \mathrm{KUHP}$ ). ${ }^{12}$

\section{Results and Discussion}

\subsection{Legal Protection On Notary Who Made A Suspect In His Duty}

Legal protection of the Notaries in performing his respective duties as General Officer has been regulated in Act No. 30 of 2004 concerning Notary and Act No. 2 of 2014 on the Amendment of Act No. 30 Of 2004 on Notary. Specifically with respect to a deed made by Notary Act No. 2 of 2014 on the Amendment of Act No. 30 of 2004 concerning Notary provide a legal protection to the Notary, as contained in the provisions of Article 4 paragraph (2) of Act No. 2 Of 2014 concerning the Oath / Promise Notary, which one paragraph reads: "that I will keep secret the contents of the deed and the information obtained in the execution of my office." the provision was further stipulated in Article 16 paragraph (1) f of Act No.

Example the problem that the land purchase deed, a husband and wife (sellers) and buyers came to the notary to be made a deed of sale. Notaries do not know that that was

\footnotetext{
${ }^{9}$ Cholid Narbuko dan H. Abu Achmadi, Metodologi Penelitian, PT. Bumi Aksara, Jakarta, 2002, p.14

${ }^{10}$ Bambang Sunggono, Metodologi Penelitian hukum, PT. Raja Grafindo Persada, Jakarta, 2003, pl.3

${ }^{11}$ Interview with Notary Anisitus A Gaham, SH, Kendal, On 7 November 2018.

${ }^{12}$ Ibid.
} 
taken by her husband (the seller) is not the legitimate wife. But the seller said that he (she) is really the only one legal wife while his legal wife at the time was located outside the city. After 1 (one) year and then turns his legal wife to come home and find the deed to the land was already there. And there is a neighbor who says the land has been sold to people for Notary A. and his wife are coming to the notary's office and will report to the police that a notary public may participate in making a false statement (Article 264 of the Criminal Code).

Before dragged a notary to criminal law to the case of giving false testimony, the investigator must know what the principal case of the case. The files submitted to the notary, because of lack of caution can make a Notary Public Notary as a suspect. Notaries in carrying out its duties only formal review as long as no element of subterfuge, of agreement evil, cheating, manipulation of data and participate falsifying documents. The task of notaries only constantire wishes of the parties who then written into deed. In this case the notary could not be convicted because there is a justification that is the reason that abolished the nature of tort. How notary prove that it was done on the basis of the justification?, attested by a notary before executing a deed, must seek approval on all concerned, especially the sellers wrote a letter whose contents explain that the vendor is a legitimate couple. This goal later when a notary is required and checked by investigators, it could be used as evidence, and this certificate must be placed within the Notary protocol. Because there is one party that is harmed in the problem, and the notary was asked by investigators to show the deed and is of public interest and to obtain permission from MKN, the Article 16 paragraph (1) f and Article 54 UUJN about keeping positions can be ruled out because there are interests that require higher notaries provide information so that the notary was released from his oath of office according to the rules applicable legislation.

Under the provisions of Act No. 2 of 2014 on the Amendment of Act No. 30 of 2004 concerning Notary above, there are at least three (3) elements that obtain legal protection. First, the evidence produced by the Notary regarding legal actions or events made law because regulations Regulations require that it be made by or before a Notary or the legal acts or legal events created for community members to ask the Notary to be made evidence that satisfies highest quality standards or the lowest accordance with the norms or rules contained in Act No. 2 of 2014. evidence it should obtain legal protection both inside the court and outside the court in accordance with the quality standards. ${ }^{13}$

Second, members of the public who mimiliki evidence produced by the Notary both required by the regulations applicable legislation or requested by members of the public. Since the early members of the public right to know the evidence which meets the quality standards of the highest and evidence which meets the quality standards of the lowest in accordance with the norms or rules contained in Act No. 2 of 2014 so that members of the public from the beginning before coming to Notary office already know the quality of products how they would earn. Members of the public who have evidence to the quality standards of the highest or lowest quality standards should obtain legal protection both inside the court and outside the court in accordance with the quality standards. ${ }^{14}$

Third, notary as an institution or public authority produces evidence for community members deserve protection from the possibility of people who assumed office as notaries who carry out the duties and authority to deviate from the Act No. 2 of 2014 on the

\footnotetext{
${ }^{13}$ Yustisia, Perlindungan Hukum Terhadap Notaris Yang Terindikasi Tindak Pindana Pembuatan Akta Otentik, article, Edition No. 2 Vol.5, 2016, p. 333.

${ }^{14}$ Ibid.
} 
Amendment of Act Number 302004 concerning Notary resulting in evidence produced does not meet the highest quality standards desired by concerned members of the public who do want evidence with low quality. People who took Notary who produce evidence to members of the public should obtain legal protection both inside the court and outside the court in carrying out its duties and authorities. ${ }^{15}$

Based on these problems from INI may provide legal protection in the form of assistance, in accordance with the Statutes and By laws of INI Organization. MKN provide legal protection to the Notary concerned with the way to approval of MKN if it will do an examination or calling the Notary, the Notary concerned objective that is not accused of leaking confidential position.

\subsection{Obstacles and Solutions of Legal Protection On Notary Who Made A Suspect In His Duty}

A Notary in carrying out his duties did not rule always in contact with legal issues, he though in the running of their office had been careful and in accordance with the provisions of the legislation. This is because the notary is an ordinary man who is not infallible. Notaries must be prepared in facing if at any time made the parties involved in the case of the field of Civil Law and Criminal Law, resulting from legal products it makes. Therefore, in performing his respective duties need not be denied again, this time quite a lot of cases-criminal cases that occur due Notary unprofessional behavior and favor one party to the deed he made. ${ }^{16}$

Law enforcement officials check Notary because there is a connection with the fact that it generates. Notary Public Notary Deed including products which can be used as evidence, in the form of instructions in an examination of the cases examined by law enforcement officials. In criminal proceedings, the instructions can be obtained from witness statements, letters and testimony of the defendant, as stipulated in Article 188 paragraph (2) of the Law of Criminal Procedure.

Before Act No. 2 of 2014 on the Amendment of Act No. 30 of 2004 concerning Notary Act. Notary examination by law enforcement officials for the benefit of the judicial process, should be done with the approval of the Supervisory Council of Regions is the assembly formed by the minister in order to exercise its authority with oversight of Notary district or city level. The authority is then deleted by the Constitutional Court Decision No. 49 / PUUX / 2012 that the verdict decide to delete the phrase "with the consent of the Assembly Regional Supervisor" contained in Article 66 paragraph (1) of Act No. 30 of 2004 concerning Notary

After the enactment of Act No. 2 of 2014 on the Amendment of Act No. 30 of 2004 on the Law Notary, the Notary inspection authority to grant approval for the benefit of the judicial process by the Act given to the Honorary Council of Notaries. Honorary Council of Notaries is an institution that by law mandated to be formed by the Minister in order to implement the guidance as set out in Article 66 A of paragraph (1) of Act No. 2 of 2014 on the Amendment of Act No. 30 Of 2004 on shrimp Act Notary.

UUJN enactment of such changes, not without obstacles in its implementation. It was mainly related to the legal protection of Notaries in the criminal justice process. Barriers based UUJN are:

\footnotetext{
${ }^{15}$ Ibid.

${ }^{16}$ Sri Utami, Perlindungan Hukum Terhadap Notaris Dalam Proses Peradilan Menurut UU Nomor 2 Tahun 2014 Tentanf Perubahan Atas UU Nomor 30 Tahun 2004 Tentang Jabatan Notaris, Jurnal, University of Sebelas Maret Surakarta, 3rd Edition January-June 2015.
} 
- The lack of a UUJN Implementing Regulation Changes ${ }^{17}$

Constraints in the rule of law are not yet implementing regulations UUJN formation changes as mandated in Article 91 B UUJN changes, so that the mechanism of investigation of the Notary still refer to the old Uun. Whereas the old UUJN has been rectified by the Constitutional Court Decision No. 49 / PUU-X / 2012 revoking Article 66 paragraph (1), in particular in terms of the obligation to obtain the consent of the Supervisory Council of Regions (MPD). It is essentially also are no longer effective with regard to the provisions of Article 14 paragraph (1) of the Regulation of the Minister of Justice and Human Rights M.03HT.0310 No. 2007 regulating the MPD. In addition, the Amendment UUJN there are several provisions stipulated in the new article may cause multiple interpretations in practice in the field, because there is no formation of implementing regulations. One such article is an obligation on the Notary to embed fingerprints as provided for in Article 16 paragraph (1) letter c. In practice, many cause unrest among clients Notary including the Bank, Financial Institution, and others. Client requests more detailed legal framework is not only based on the provisions of Article 16 paragraph (1) $c$ and has the force of law.

- The lack of a Notary Honorary Council (MKN) ${ }^{18}$

In the interests of judicial proceedings, investigators, public penuntt or judges when they want to take photocopies minuta or call Notary deed itself subject to approval of the Supervisory Council of Regions (MPD). However, the phrase "with the consent of MPD" has been canceled by the Constitutional Court decision of the Constitutional Court Number 49 / PUU-X / 2012. However, the new UUJN to reinsert "protection" these Notary through the phrase "with the consent of the Notary Honorary Council (MKN)". MKN has not been established, because the basis of its formation by regulation. Meanwhile, until the current regulation as the legal basis formation of MKN as mandated in Article 66 and 66A UUJN changes yet. Therefore, the agency has not terbentukya MKN become an obstacle in providing legal protection for the Notary, especially in the criminal justice process. Thereby, currently in the calling process by investigator against Notary suspected of committing a criminal offense or as a witness, the mechanism can calling directly to the Notary concerned, without going through the MPD or MKN.

- INI role to socialize UUJN Changes in certain areas less ${ }^{19}$

Outreach activities important to remember the need for a deep understanding of the multiple changes of UUJN that have been enacted since 2014. Basically socialization UUJN changes made as a form of unification of views in practice for the Notary. Nevertheless, the role of IT to conduct socialization about this UUJN changes in certain areas is still lacking.

The constraints mentioned above, it is necessary to solutions to overcome them. How to overcome these obstacles is the way the government immediately establish Peraturann Implementing UUJN so as not to cause multiple interpretations, either alone or Client in Public Notary. Furthermore, there should be assistance to notaries who used sebgai suspects before the MKN formed and enhance the role of both INI internal and external. ${ }^{20}$ Barriers that occur according to the Notary Anisitus A. Gaham in practice in the field are: First, the investigator did not ask for permission or opinion of the expert witness Notary profession before and after the set becomes a suspect.

\footnotetext{
${ }^{17}$ Ibid.

${ }^{18}$ Ibid.

${ }^{19}$ Ibid.

${ }^{20}$ Ibid.
} 
Volume 5 Issue 4, December 2018

Second, the suspect or the Notary not ask the investigator or the prosecutor or the court to ask the expert witnesses of the Notary profession.

Third, the number of expert witnesses from regions (Pengda/Pengwil/Supervisory Center) who do not understand the law of criminal procedure, so that the expert witness testimony many not be used by law enforcement because of his testimony to defend without a legal basis, while the task of the expert witness actually gave opinions on formalities and the substance of the Notary and PPAT deed.

Fourth, the number of expert witnesses who ask for a fee to members (Notary) so straining Notary suspects.

The solution of the constraints that occur in the field is the investigator must ask permission or opinion of an expert witness from the profession Notary before and after the set as a suspect, the suspect or the Notary should ask the investigator or the prosecutor or the court to ask the expert witness testimony from Notary profession, the expert witness of the areas (Pengda /Pengwil/Supervisory Center) should be understood so that the criminal procedure law expert witnesses used by law enforcement for his statement on the basis of legal, expert witnesses are not allowed to charge to the Notary used as a suspect.

\section{Closing}

\subsection{Conclusion}

- Legal Protection On Notary Who Made A Suspect In His Duty

In the case of notaries serve as a suspect, the notary is also entitled to be informed clearly in a language understood by him about what coercing him at the time of the exam begins (Article 51 of the Criminal Procedure Code). The suspect has the right to provide information freely to the investigator. In the examination of the level of investigation and trial, the suspect has the right to provide information freely to the investigator or a judge (Article 52 of the Criminal Procedure Code). Before dragged a notary to criminal law, the investigator must request permission in advance to the Honorary Council of the Notary if will check or calling the notary. The goal is that the notary is not suspected of leaking secrets of office.

- Obstacles and solutions legal protection against notaries who serve as a suspect in performing his respective duties: (1) There UUJN formation Changes Implementing Regulations; (2) There Notary formation of the Honorary Council (MKN); (3) The role of INI to socialize UUJN Changes in certain areas less. While based practice, obstacles encountered, namely First, the investigator did not ask for permission or opinion of the expert witness Notary profession before and after the set becomes a suspect. Second, the suspect or the Notary not ask the investigator or the prosecutor or the court to ask the expert witnesses of the Notary profession. Third, the number of expert witnesses from regions (Pengda/Pengwil/Supervisory Center) who do not understand the law of criminal procedure, so that the expert witness testimony many not be used by law enforcement because of his testimony to defend without a legal basis, while the task of the expert witness actually gave opinions on formalities and the substance of the Notary and PPAT deed. Fourth, the number of expert witnesses who ask for a fee to members (Notary) so straining Notary suspects.

\subsection{Suggestion}

- For the Supervisory Council in order to supervise the Notary office tasks, the goal for Notaries can perform his duties in accordance with Law Notary and Notary Code. And for the Honorary Council of Notaries to conduct inspection in accordance with the rules 
of law.

- Notaries must be protected in the running of their office, so as to minimize the misunderstanding that often occurs in the field, the INI Organization in order to disseminate to various areas held uninformed about UUJN or code of conduct notary so not many notaries are dragged into the realm of criminal/invoked by investigators because of misunderstanding.

\section{Bibliography}

\section{Book}

[1] Abdul Ghofur Anshori. 2009. Lembaga Kenotariatan Indonesia, Perspektif Hukum dan Etika.Yogyakarta : UII Press.

[2] Bambang Sunggono.2003.Metodologi Penelitian hukum.Jakarta : PT. Raja Grafindo Persada.

[3] Cholid Narbuko dan H. Abu Achmadi. 2002. Metodologi Penelitian.Jakarta : PT. Bumi Aksara.

[4] Mochtar Kusumaatmadja.2000. Pengantar IImu Hukum Suatu Pengenalan Pertama Ruang Lingkup Berlakunya IImu Hukum.Bandung : Alumni.

[5] Sudikno Mertokusumo.2003. Mengenal Hukum Suatu Pengantar.Yogyakarta :Liberty.

[6] Tan Thong Kie. 2000.Studi Notariat. Jakarta : PT. Ichtiar Baru Van Hoeve.

[7] Yustisia. Perlindungan Hukum Terhadap Notaris Yang Terindikasi Tindak Pindana Pembuatan Akta Otentik. Artikel. Edisi No. 2 Vol.5, 2016.

\section{Legislation}

[1] Book of Criminal Law (Criminal Code) No. 8 of 1981

[2] Book of Civil Law (Civil Code)

[3] The Code of Penal

[4] Regulation of the Minister of Law and Human Rights No. M.03.HT.10 2007

[5] Act No. 30 of 2004 concerning Notary

[6] Act No. 2 of 2014 concerning Notary

\section{Scientific journals}

[1] Irawan Arif Firmansyah, Sri Endah Wahyuningsih. 2017. Peran Notaris Sebagai Saksi Dalam Proses Peradilan Pidana, Jurnal Akta, Universitas Islam Sultan Agung Semarang, Vol. 4 dated 3 september.

[2] Sri Utami. 2015. Perlindungan Hukum Terhadap Notaris Dalam Proses Peradilan Menurut UU Nomor 2 Tahun 2014 Tentanf Perubahan Atas UU Nomor 30 Tahun 2004 Tentang Jabatan Notaris, Jurnal, Universitas Sebelas Maret Surakarta, Edition 3 January- June url : https://media.neliti.com/media/publications/14072-IDperlindungan-hukum-bagi-notaris-untuk-menjaga-kerahasiaan-isi-akta-yangdiperbua.pdf

[3] Widyatmoko. 2014. 'Analisis Kritis Membedah Ketentuan Undang-undang Perubahan Atas Undang-undang Nomor 30 Tahun 2004 (UUJN)", Seminar Nasional, held by Master of Notary Law, Faculty of Law, University of Sebelas Maret, Surakarta. p.1. dated 16 January. 